\title{
Internal Flow of a High Specific-Speed Diagonal-Flow Fan (Rotor Outlet Flow Fields with Rotating Stall)
}

\author{
Norimasa Shiomi, Wen-Xin Cai, Akio Muraoka, Kenji Kaneko, \\ and Toshiaki Setoguchi \\ Department of Mechanical Engineering, Saga University, Saga, Japan
}

We carried out investigations for the purpose of clarifying the rotor outlet flow fields with rotating stall cell in a diagonal-flow fan. The test fan was a high-specific-speed $\left(n_{s}=1620\right)$ type of diagonal-flow fan that had 6 rotor blades and 11 stator blades. It has been shown that the number of the stall cell is 1 , and its propagating speed is approximately $80 \%$ of its rotor speed, although little has been known about the behavior of the stall cell because a flow field with a rotating stall cell is essentially unsteady. In order to capture the behavior of the stall cell at the rotor outlet flow fields, hot-wire surveys were performed using a single-slant hotwire probe. The data obtained by these surveys were processed by means of a double phase-locked averaging technique, which enabled us to capture the flow field with the rotating stall cell in the reference coordinate system fixed to the rotor. As a result, time-dependent ensemble averages of the three-dimensional velocity components at the rotor outlet flow fields were obtained. The behavior of the stall cell was shown for each velocity component, and the flow patterns on the meridional planes were illustrated.

Keywords Fan, Internal flow, Rotating stall, Stall cell, Unsteady flow

A diagonal-flow fan has relatively high efficiency, a low noise level, and a wide operating range. However, when its specific speed becomes high, its pressure/flow-rate curve tends to indicate unstability by a positive gradient in the low flow range that is similar to that of an axial-flow fan. It is well known that the rotating stall is the main cause of this unstable characteristic, and a flow field with a rotating stall indicates remarkable un-

Received 25 June 2002; accepted 1 July 2002.

Address correspondence to Norimasa Shiomi, Department of Mechanical Engineering, Saga University, 1, Honjo-machi, Saga, 8408502, Japan. E-mail: siomi@me.saga-u.ac.jp steadiness, with partly reversed flow. For axial turbomachines, many researchers (Inoue et al., 2000; Kuroumaru et al., 1999; Moore and Greitzer, 1986; Poensgen and Gallus, 1996; SaxerFelice et al., 1998) have investigated the flow field with a rotating stall cell. However, there are very few studies of unsteady flow fields in diagonal-flow fans. Kaneko and colleagues (1993, 1995, 1997) tried to measure an unsteady flow field with a rotating stall in a high-specific-speed diagonal-flow fan using hot-wire and pressure probes. From that series of studies the unsteady flow characteristics of a rotating stall cell were clarified to some extent. Since then, Shiomi and colleagues (2000) have reported the behavior of a stall cell in a pressure field using a total pressure probe in a high-specific-speed diagonal-flow fan, but the detailed flow pattern has been unknown.

Most surveys of the internal flow fields of turbomachines have been performed using a phase-locked averaging technique, because the flow field includes the periodical fluctuations caused by the rotor blades' passing. Under rotating stall conditions, however, another fluctuation caused by the stall cell's propagating at a speed different from that of the rotor is superimposed on the flow field. Therefore, it is impossible to analyze a flow field with a rotating stall cell by using the ordinary phase-locked averaging technique. In order to clarify a flow field with a rotating stall cell and the behavior of the stall cell, a so-called double phase-locked averaging (DPLA) technique was developed by Kuroumaru and colleagues (1999); it enables analysis of a flow field with a rotating stall cell in the reference coordinate system fixed to the rotor. With this method, it is assumed that the propagating speed of the stall cell is constant.

In this study, the experimental investigation of an unsteady flow field with a rotating stall cell was carried out in a highspecific-speed diagonal-flow fan at Saga University in Japan. The hot-wire surveys were performed at three rotor outlet planes using a single-slant hot-wire probe. Those data were processed by using the DPLA technique and time-dependent ensemble averages of the three-dimensional velocity components, that is, meridional velocity component $\mathrm{V}_{\mathrm{m}}$, circumferential velocity component $\mathrm{V}_{\theta}$, and spanwise velocity component $\mathrm{V}_{\mathrm{n}}$ were 


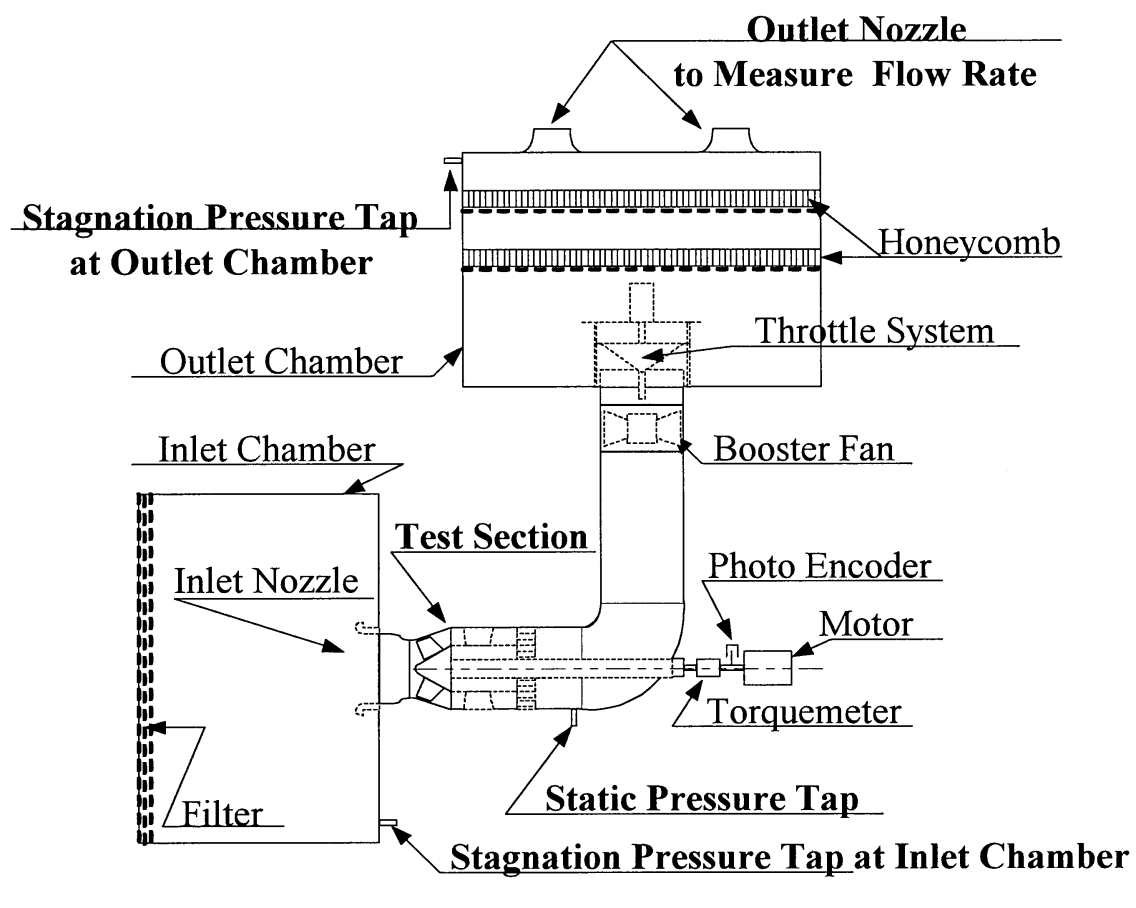

FIGURE 1

Schematic layout of test rig.

obtained. Stall cell propagation was drawn on each velocity component's contour map, and the behavior of the stall cell was clarified. Also, the outline of the flow pattern on some meridional planes are illustrated.

\section{EXPERIMENTAL FACILITY AND INSTRUMENTATION}

The experiments were carried out using a high-specific-speed diagonal-flow fan (Figure 1) at Saga Unversity in Japan. It consists of a rotor with a $310-\mathrm{mm}$ diameter at the tip of blade's leading edge, a $347-\mathrm{mm}$ diameter at the tip of blade's trailing edge, and an outlet with a diameter of $380 \mathrm{~mm}$. The hub-to-tip ratio at the stator was 0.6 . The rotor comprises 6 blades that were designed by using a quasi-three-dimensional method based on the two-dimensional cascade data. The rotor was manufactured precisely by a numerically controlled (NC) milling machine to secure the geometry of the blade. The stator comprises 11 blades. Selection of its blade elements was carried out using twodimensional cascade data for a circular-arc blade. This diagonalflow fan stage has the flow rate coefficient of $\phi=0.345$, and the total pressure coefficient of $\psi=0.250$ at the design point. The specific speed of the test fan is $1620 \mathrm{rpm}\left(\mathrm{m}^{3} / \mathrm{min}, \mathrm{m}\right)$. Although this is a relatively high value for a diagonal-flow fan, it was chosen to allow comparison to the flow field of an axial compressor, for which the research on unsteady flow in the rotating stall region has been actively done. The blade tip clearance (TC) of the rotor was $0.5 \mathrm{~mm}(0.45 \%$ of the blade height at the leading edge). Additional information concerning the test fan, rotor, and stator is shown in Table 1.
The stage performance was evaluated for a combination of this rotor and stator. The total pressure rise of the stage was obtained from the pressure difference between the inlet and outlet chamber by subtracting the aerodynamic loss of the other element. The flow rate was measured by using a flow nozzle that was attached to the outlet chamber. The torque was measured by using a torque meter mounted on the rotor shaft, as shown in Figure 1.

The internal flow field surveys made in the diagonal-flow fan were made by a single-slant hot-wire, which was tungsten

TABLE 1

Specifications of the Test Fan, Rotor, and Stator

Test fan

$\begin{array}{lc}\text { Total pressure coefficient } & \phi=0.250 \\ \text { Flow coefficient } & \phi=0.345 \\ \text { Specific speed } & \mathrm{n}_{\mathrm{s}}=1620 \\ \text { Angle of casing } & 20^{\circ} \\ \text { Angle of hub } & 40^{\circ} \\ \text { Hub ratio (at stator) } & 0.6\end{array}$

Rotor and stator

Blade section

Number of blade

Mean solidity

\begin{tabular}{cc} 
Rotor & Stator \\
\hline NACA65 & Circular arc \\
6 & 11 \\
0.88 & 1.30 \\
0.79 & 0.67
\end{tabular}

Mean aspect ratio

Vortex design

Free vortex Free vortex 

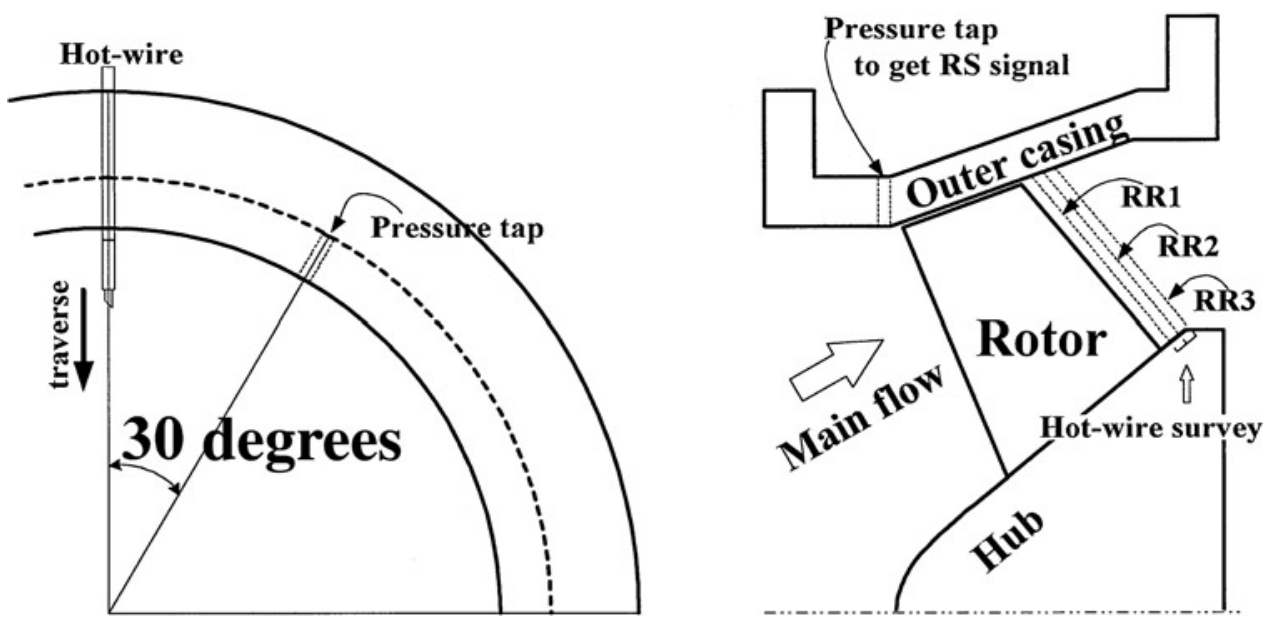

FIGURE 2

Schematic view of test section and measuring location.

filament $5 \mu \mathrm{m}$ in diameter and $1 \mathrm{~mm}$ in effective length, with a 45-degree slant angle. In order to utilize the DPLA technique, it is necessary to take two periodic trigger signals that have different frequencies. One is the rotating stall cell reference signal, and the other is the rotor blade's rotation signal. The former is the low-pass filter (LPF) signal from the pressure transducer (Entran EPE-58) output through a 50-Hz low-pass filter on the casing wall upstream of the rotor. Its transducer has natural frequency of $80 \mathrm{kHz}$ and a pressure range of $14 \mathrm{kPa}$, and is mounted on the outer casing $5 \mathrm{~mm}$ upstream of the rotor's leading edge, as shown in Figure 2, which is from a photo-encoder mounted on the rotor shaft, as shown in Figure 1.

\section{MEASUREMENTS AND PROCEDURES}

The hot-wire traverses were carried out at the rotor outlet at three survey planes: RR1, RR2, and RR3, as shown in Figure 2. Its distances from the rotor's trailing edge were 5, 10, and $15 \mathrm{~mm}$, respectively. There were nine spanwise measurement points at each traverse station. As it is known that the rotating stall cell exists near the blade tip in this fan, the distances between the spanwise measurement points near the blade tip is smaller than the distances near the rotor hub. For each measurement point, the hot-wire probe was rotated about its axis 360 degrees at intervals of 36 degrees.

In order to utilize the DPLA technique, it is necessary to get two trigger signals; one is the signal related to the rotor blade's passing, and the other is the signal related to the stall cell's propagation. In this case, it was assumed that the rotating stall cell propagated at a constant speed. The former is obtained from photo-encoder mounted on the rotor shaft, as shown in Figure 1. The latter is taken by setting a threshold level for the LPF signal of the pressure transducer, in which the blade-passing frequency has been removed. It is mounted $5 \mathrm{~mm}$ upstream of the rotor's leading edge and its circumferential position is shifted 30 degrees from the hot-wire traverse station, as shown in Figure 2.
At each fixed location of the hot-wire sensor, the number of circumferential sampling points per rotor rotation was 387 , and data were acquired for approximately 1500 rotor rotations. At the same time, the LPF pressure signal on the casing wall was acquired to obtain the reference position of a stall cell relative to a blade. The DPLA technique was applied to these data to get the time-dependent average phase locked to both the rotor and the cell rotation; that is, these data were classed into 10 windows corresponding to the relative circumferential positions of the stall cell in a blade spacing. Thus, conditional sampling and averaging were made synchronously with the rotor and the cell rotation.

The location of a stall cell relative to a blade was determined as follows. To help explain the DPLA technique, an example of the data is shown in Figure 3: (a) is the raw pressure data from the pressure transducer mounted on the casing wall; (b) is the LPF rotating stall cell reference signal; (c) is the rotor blade's signal obtained from the photo-encoder output. In each part, the ordinate is time, and these three elements are acquired at the same time. First, the rotating stall reference point $\left(\mathrm{RS}_{\mathrm{ref}}\right)$ is determined from the rotating stall reference signal (Figure $3 b$ ). $\mathrm{RS}_{\text {ref }}$ is the point where the rotating stall cell signal crosses its averaged value from negative to positive. Also, the interval between one $\mathrm{RS}_{\text {ref }}$ and next $\mathrm{RS}_{\text {ref }}$ corresponds to a period of traveling by the stall cell. It is called $\mathrm{RS}_{\text {len }}$ and the average size of the stall cell is determined. Second, the raw pressure data are divided into the data block; its starting point corresponds to $\mathrm{RS}_{\text {ref }}$ and its size corresponds to the average size of the stall cell. Third, blade spacing is divided into 10 windows, as shown in Figures $3 \mathrm{c}$ and $3 \mathrm{~d}$. In this study, these windows are called trigger points (TP). Fourth, the TP into which $\mathrm{RS}_{\text {ref }}$ belongs is determined. For example, in Figure 3, $\mathrm{RS}_{\text {ref }}(\mathrm{i}-1)$ belongs in $\mathrm{TP}=4$; $\mathrm{RS}_{\text {ref }}(\mathrm{i})$ belongs in $\mathrm{TP}=5$; and $\mathrm{RS}_{\text {ref }}(\mathrm{i}+1)$ belongs in $\mathrm{TP}=2$. Then corresponding data blocks are labeled as follows: raw pressure data between $\mathrm{RS}_{\text {ref }}(\mathrm{i}-1)$ and $\mathrm{RS}_{\text {ref }}(\mathrm{i})$ are labeled $\mathrm{TP}=4$; the data between $\mathrm{RS}_{\text {ref }}(\mathrm{i})$ and 
(a)

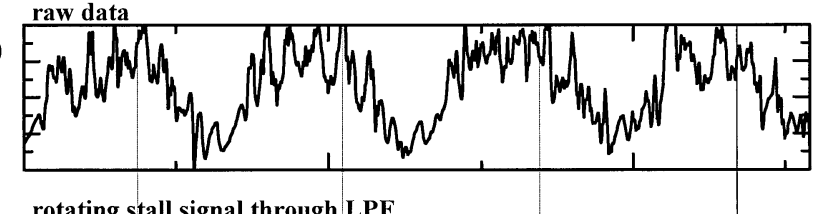

(b)

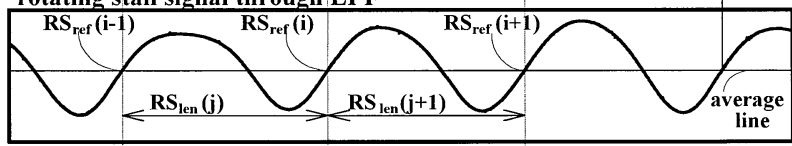

(c)

(d)

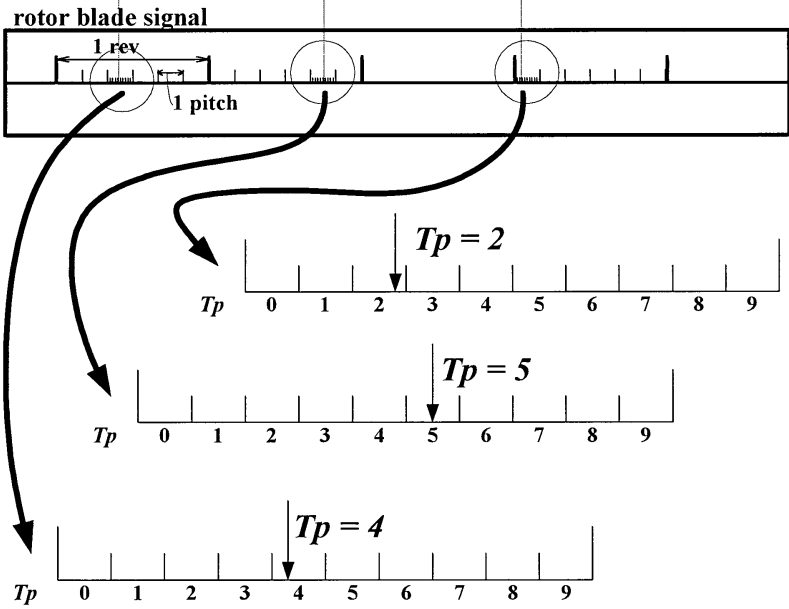

FIGURE 3

Outline of DPLA technique.

$\mathrm{RS}_{\text {ref }}(\mathrm{i}+1)$ are $\mathrm{TP}=5$; and the data between $\mathrm{RS}_{\text {ref }}(\mathrm{i}+1)$ and the next $\mathrm{RS}_{\text {ref }}$ are $\mathrm{TP}=2$. Finally, all data belonging to the same $\mathrm{TP}$ are averaged at each sampling point. However, one should notice that this averaged data set would not constitute a velocity distribution synchronous with the cell rotation, because the rotational speed of the cell is different from the rotor speed. As the data acquired at a fixed location synchronously with the rotor rotation, the time delay between $\mathrm{RS}_{\text {ref }}$ and a data sampling point causes the relative location of the stall cell to shift. Therefore, the location of $\mathrm{RS}_{\text {ref }}$ for each data sampling point should be modified. Such a modification is made by assuming that $\mathrm{RS}_{\text {ref }}$ would travel at a constant speed.

\section{RESULTS AND DISCUSSION}

\section{Overall Characteristics of the Test Fan}

The performance characteristics of the test fan are shown in Figure 4, where the abscissa indicates the total pressure coefficient $(\psi)$, total pressure efficiency $(\eta)$, and torque coefficient $(\tau)$, and the ordinate represents the flow rate coefficient $(\phi)$. When the flow rate coefficient is reduced from the design point (DP in Figure 4), the sharp drop in the total pressure coefficient occurs near $\phi=0.200$. It was explained by Kaneko and colleagues $(1993,1995,1997)$ that this sharp drop in the total pressure coefficient is caused by the occurrence of a rotating stall with one cell, and its propagating speed is approximately $80 \%$ of the rotor speed. In order to clarify the behavior of the rotating stall

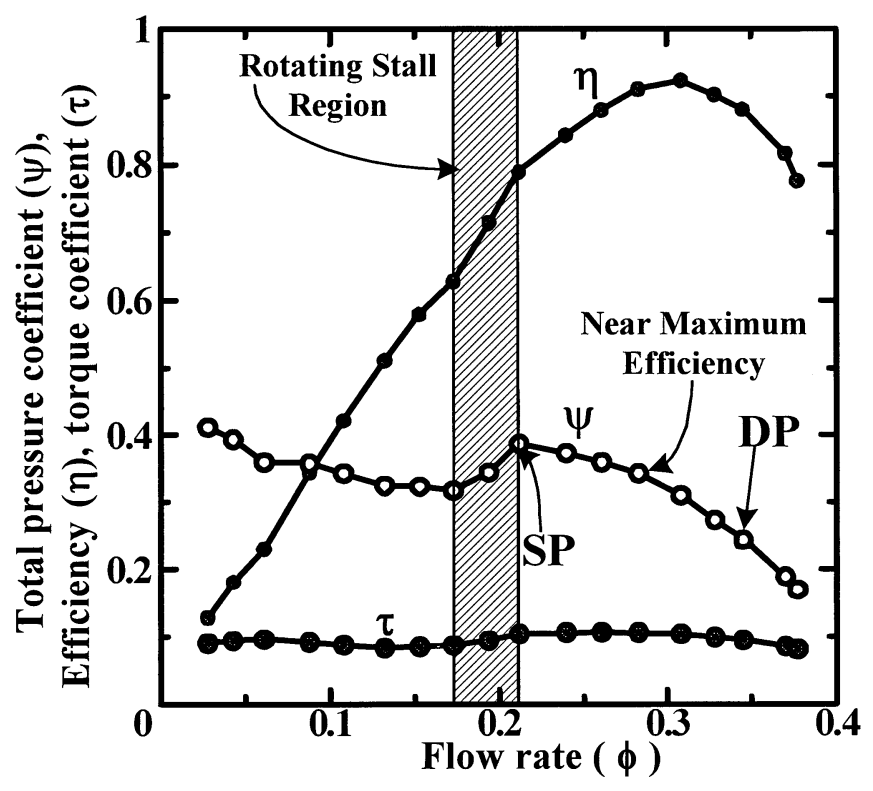

FIGURE 4

Characteristic curves of test fan.

cell, internal flow surveys were conducted at this stall condition $(\phi=0.195)$.

To enable a comparison with stable conditions, flow surveys at the stall point ( $\mathrm{SP}$ in Figure 4, $\phi=0.210$ ), near maximum efficiency point $(\phi=0.280)$, and design point (DP in Figure 4, $\phi=0.345)$ were also carried out.

\section{Meridional Velocity Distributions at RR1}

Figure 5 shows the contour maps of the meridional velocity $\left(\mathrm{V}_{\mathrm{m}}\right)$ at the rotor outlet (RR1) under the rotating stall condition in which there is progressing TP. In order to compare this with the rotor inlet flow field, the rotor inlet flow field under the rotating stall condition at $\mathrm{TP}=0.0$ is shown in Figure 6. And Figure 7 shows the contour maps of $\mathrm{V}_{\mathrm{m}}$ at RR1 under higher flow-rate conditions, that is, $\phi=0.210,0.280$, and 0.345 . In all the figures, the abscissa and ordinate indicate the spanwise direction and blade pitches, respectively. TP represents the location of the stall cell relative to a rotor blade, and in these figures, the rotating stall cell moves one blade pitch of the rotor blade row from $\mathrm{TP}=0.0$ to $\mathrm{TP}=1.0$. The bold black lines in each figure show the blade edges. The blade-rotating direction is from right to left, as is indicated at the tops of these figures. In Figure 5, the reversed-flow region is indicated by green, and the blue line is drawn from the edges of the stall cell at $\mathrm{TP}=0.0$ to $\mathrm{TP}=1.0$; the maximum value of $\left(\mathrm{V}_{\mathrm{m}} / \mathrm{U}_{\mathrm{t}}\right)$ is approximately 0.25 , and the minimum value is approximately -0.05 .

In Figure 5, the flow field inside the blade passages is roughly divided into two types; one is the flow field with a reversed flow region, the other is without a reversed flow region. A series of blade pitches where reversed flow occurs is the region affected by the stall cell, and this region is moving from left to right with progressing TP, as shown in Figure 5. Its direction is opposite 


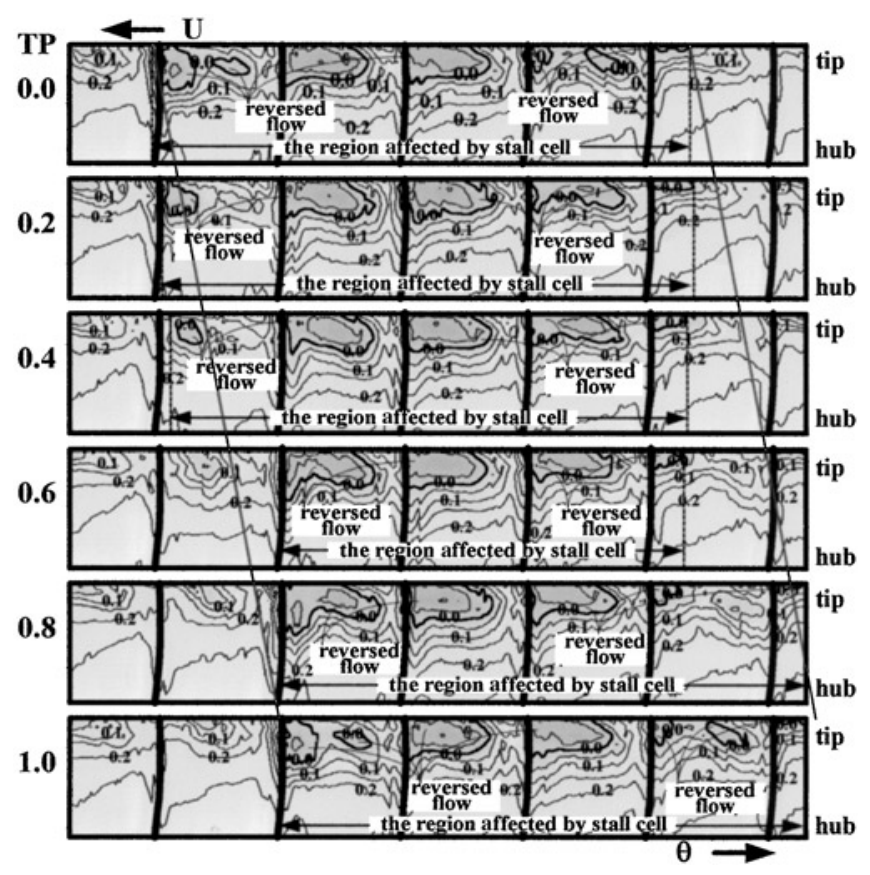

FIGURE 5

Transition of meridional velocity distributions with progressing $\mathrm{TP}$ (RR1, rotating stall condition).

to the direction at which the blade is moving. In this article, the right edge of the stall cell is defined as the cell because the stall cell is propagating at the right relative to the rotor blade.

Comparing Figure 5 with Figure 6, it is found that the spanwise extent of the reversed flow region (stall cell) at the rotor outlet flow field is larger than it is at the rotor inlet, although the circumferential extent of the stall cell is almost the same. This means that the separated region on blade suction surface (SS) is extended to near the midspan of the rotor blade at the blade trailing edge, while it is limited to the near blade tip at the blade leading edge. Also, it is seen that the location of the strongly reversed flow is different between the rotor inlet and the outlet, that is, at the rotor inlet, the reversed flow region concentrates on the blade pressure surface (PS) near the blade tip. On the other hand, at the rotor outlet it extends from the blade's SS to the blade's mid-pitch. This difference is caused by its occurrence mechanism; at the rotor inlet, the flow, which cannot enter into the blade passage due to flow separation on blade SS, is pushed

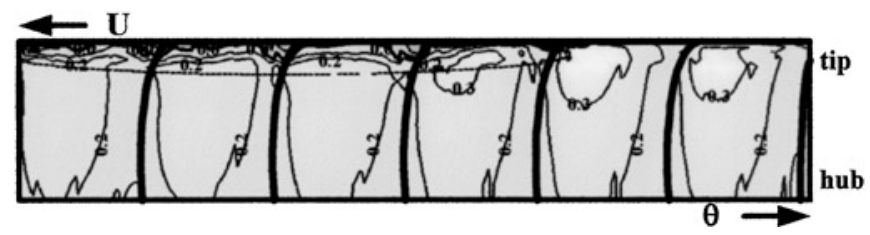

FIGURE 6

Contour map of meridional velocity distribution at $\mathrm{TP}=0.0$ ( $5 \mathrm{~mm}$ upstream of rotor, rotating stall condition).

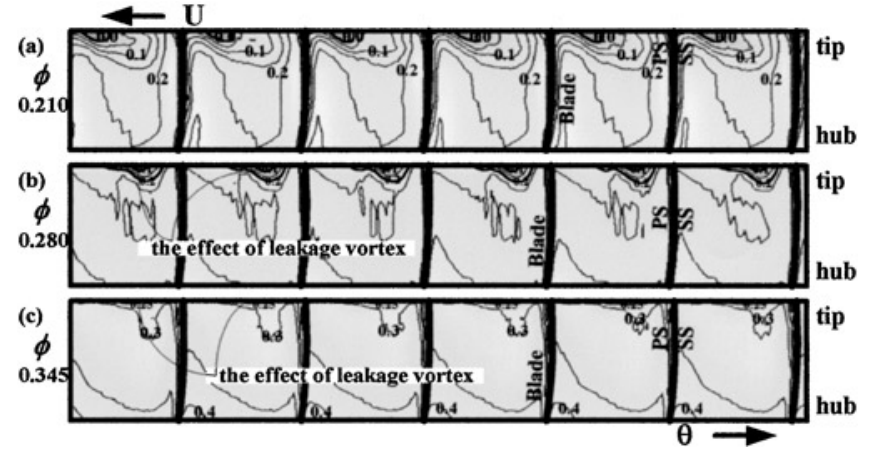

FIGURE 7

Contour maps of meridional velocity distributions (RR1, nonstall condition).

back to upstream of the rotor near the blade PS, whereas downstream of rotor, the flow is drawn into the low-pressure area caused by flow separation downstream of the rotor.

Observing the detailed motion of the cell, it is found that the moving speed of each cell edge is different with progressing TP. First, between $\mathrm{TP}=0.0$ and $\mathrm{TP}=0.4$, the cell's leading and its trailing edge move slowly. Second, between $\mathrm{TP}=0.4$ and TP $=0.6$, the cell's trailing edge moves quickly, while the cell's leading edge moves slowly. Therefore, the circumferential size of the cell becomes the smallest at this moment. Third, between TP $=0.6$ and $\mathrm{TP}=0.8$, the cell's leading edge moves quickly, but the cell's trailing edge moves slowly. This means that the stall cell is propagating by changing its circumferential size, although the stall cell is moving at a constant speed as a whole.

The low value regions of $\mathrm{V}_{\mathrm{m}}$ near the outer casing outside the cell correspond to the region affected by the tip leakage vortex, as shown in Figure 7: $\phi=0.280$ and 0.345. For $\phi=0.210$, there exist periodical reversed flow regions. These regions are not caused by flow separation on blade SS, but seem to be caused by the breakdown of the tip leakage vortex (Kaneko et al., 2000).

\section{Circumferential Velocity Distributions at RR1}

Figure 8 shows the contour maps of the circumferential velocity $\left(\mathrm{V}_{\theta}\right)$ at RR1 under the rotating stall condition with progressing TP. The abscissa and ordinate are the same as in Figures 5, 6 , and 7.

As in the meridional velocity distributions, it is also seen that the extent of the spanwise direction of the cell at the rotor outlet is larger than at rotor inlet, although its circumferential extent is almost the same at both rotor outlet and inlet. The area that has a large value of $\mathrm{V}_{\theta}$ exists near blade SS at both the rotor inlet and the outlet. This means that the separated flow on blade SS is traveling with the rotor blade. However, the location of the maximum value of $\mathrm{V}_{\theta}$ is different at the rotor inlet and the outlet. Its location is near mid cell at the rotor inlet, whereas its location is near the cell's trailing edge at the rotor outlet. Comparing the flow field under rotating stall conditions with 


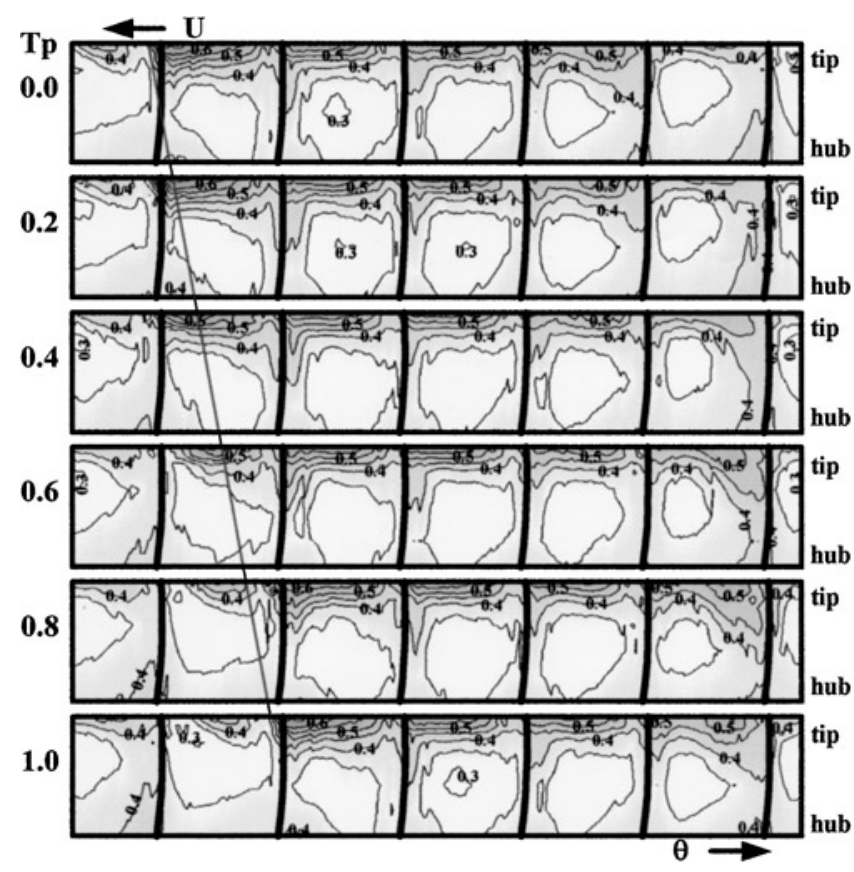

FIGURE 8

Transition of circumferential velocity distributions with progressing TP (RR1, rotating stall condition).

high flow-rate conditions, the value of $\mathrm{V}_{\theta}$ under rotating stall conditions is larger than under higher flow-rate conditions. The distribution of $\mathrm{V}_{\theta}$ outside the cell under rotating stall conditions is similar to those of higher flow-rate conditions.

\section{Spanwise Velocity Distributions at RR1}

Figure 9 shows the contour maps of the spanwise velocity $\left(\mathrm{V}_{\mathrm{n}}\right)$ at RR1 under rotating stall conditions with progressing TP. Figure 10 shows the contour maps of $V_{n}$ at RR1 under higher flow-rate conditions. It is noted that the direction of the spanwise velocity is parallel to the probe axis. Therefore, when the flow is parallel to the hub, the value of $\mathrm{V}_{\mathrm{n}}$ becomes approximately zero, and when the flow is parallel to the outer casing, its value indicates minus.

Comparing Figure 9 with Figure 10, it is seen that there exist obvious differences for the value of $V_{n}$. In Figure 10, the value of $V_{n}$ for all flow rates indicates mainly minus. On the other hand, in Figure 9, its value shows plus, both inside and outside of the cell, so that it is found that the flow is outward as a whole under rotating stall conditions. Especially, its value is larger near blade SS than in other regions. This means that the separated flow on blade SS is transported outward due to centrifugal force.

\section{Comparison of Velocity Fields at Various Measurement Planes}

Figure 11 shows the comparison of distributions of $\mathrm{V}_{\mathrm{m}}$ at three measurement planes, at $\mathrm{TP}=0.0$, and under rotating stall

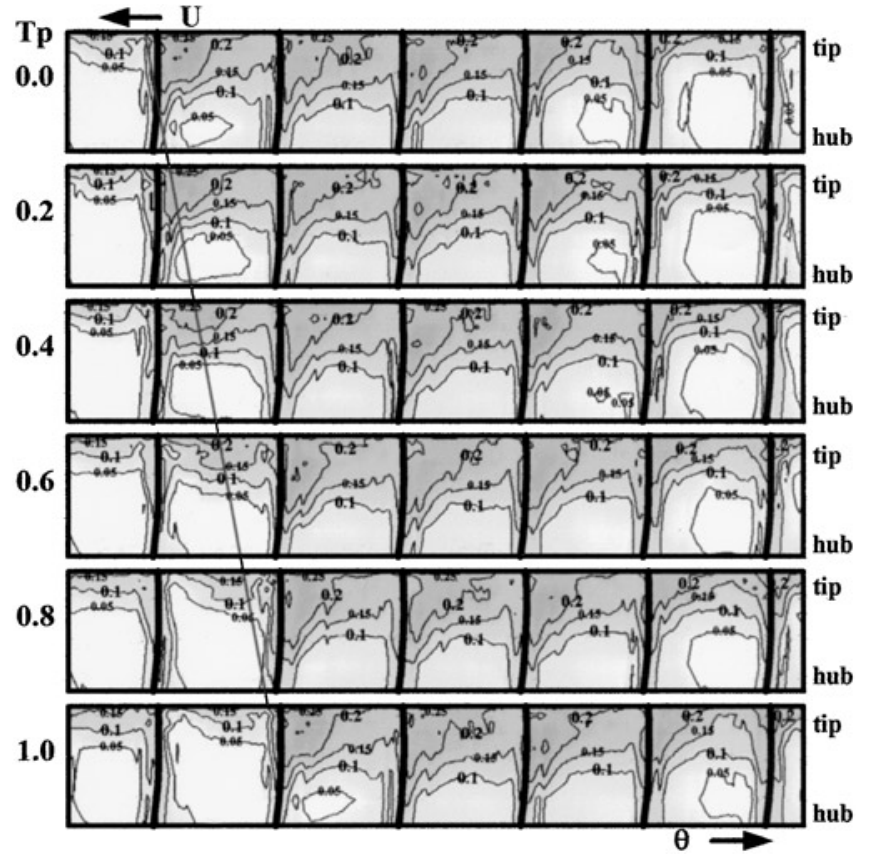

FIGURE 9

Transition of spanwise velocity distributions with progressing TP (RR1, rotating stall condition).

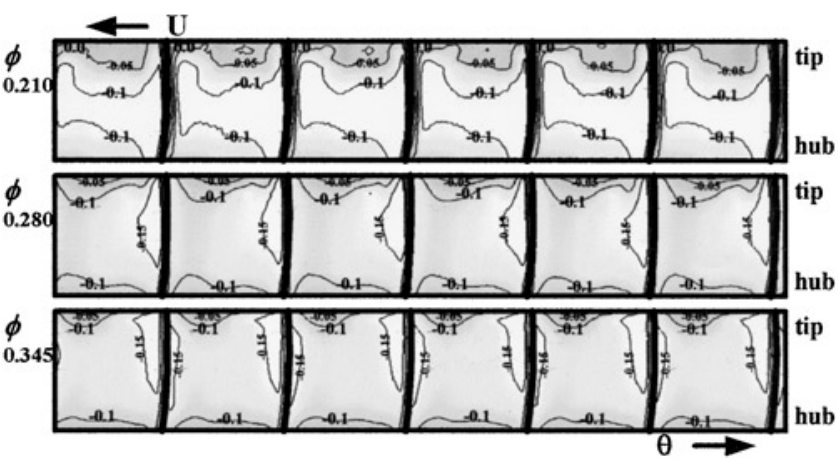

FIGURE 10

Contour maps of spanwise velocity distributions (RR1, nonstall condition).

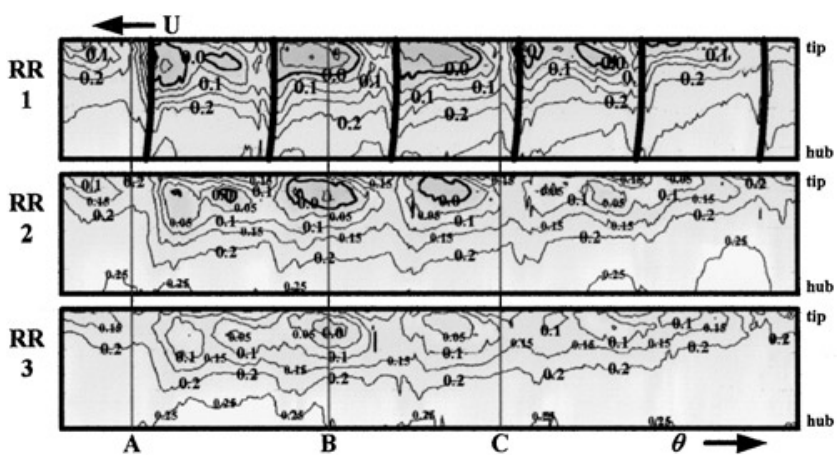

FIGURE 11

Comparison of meridional velocity distributions at three measurement planes ( $\mathrm{TP}=0.0$, rotating stall condition). 
(a)

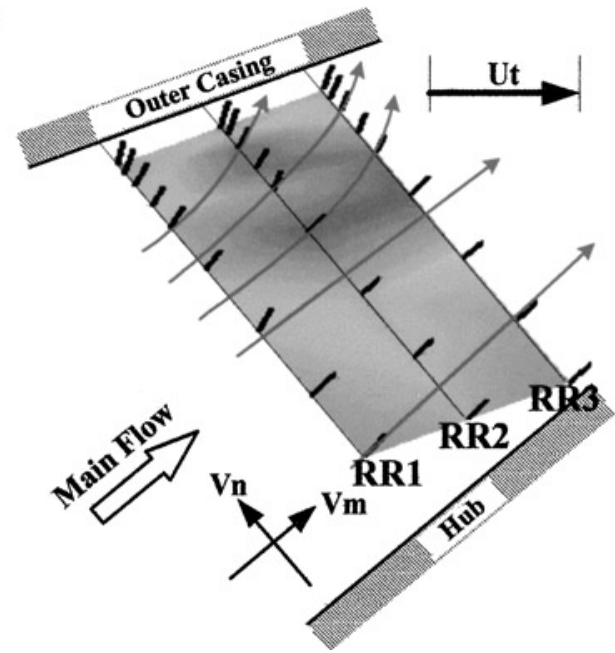

(b)

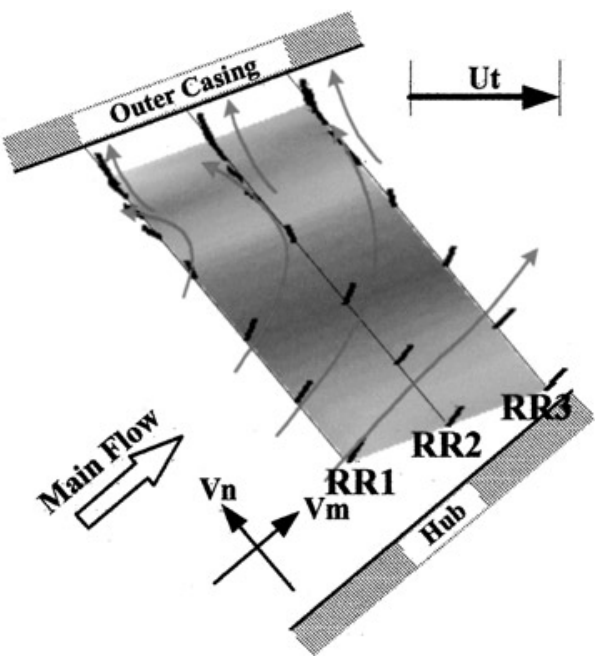

(c)

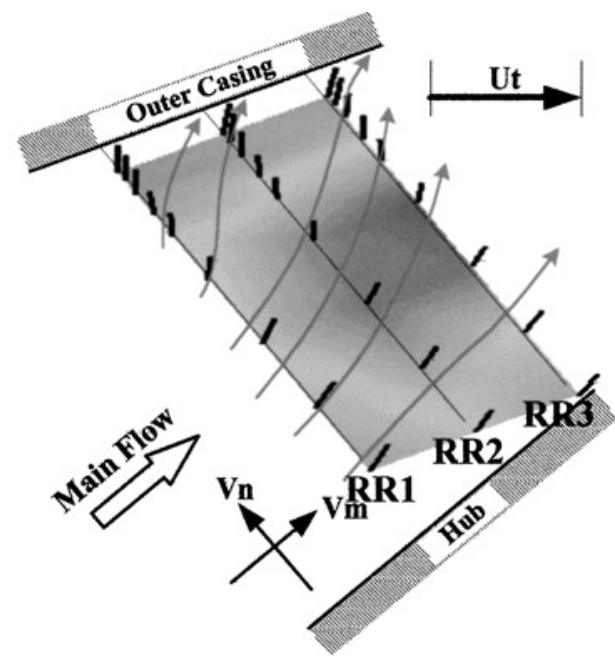

FIGURE 12

Flow pattern on meridional plane behind rotor $(\mathrm{Tp}=0.0$, rotating stall condition). (A) Outside the cell (A line in

Figure 11). (B) Inside the cell where strongly reversed flow is observed (B line in Figure 11). (C) Inside the cell where the reversed flow is not observed (C line in Figure 11). conditions. The top picture in Figure 11 is for the RR1 plane; the middle is the RR2 plane, and the bottom is the RR3 plane, respectively.

It is observed that the reversed-flow region is rapidly reduced as its distance becomes far from the rotor's trailing edge. However, the large changes are not observed for the contour line of $\mathrm{V}_{\mathrm{m}}=0.2$, even if the distance is far from the rotor. On the other hand, the region of $\mathrm{V}_{\mathrm{m}}>0.25$ is reduced with distance from rotor. To generalize: the flow field tends to be uniform as the distance from the rotor becomes far.

\section{Flow Pattern on the Meridional Plane Downstream of the Rotor}

Figures $12 \mathrm{a}, 12 \mathrm{~b}$, and $12 \mathrm{c}$ show the outline of flow patterns on the meridional plans at $\mathrm{TP}=0.0$ under rotating stall conditions. The cross sections $\mathrm{A}, \mathrm{B}$, and $\mathrm{C}$ correspond to lines $\mathrm{A}, \mathrm{B}$, and $\mathrm{C}$ in Figure 11. The cross section A shown in the top figure of Figure 12 corresponds to the outside region of the cell; B shown in the middle figure of Figure 12 corresponds to the inside region of the cell with strongly reversed flow, and $\mathrm{C}$ shown in the bottom figure of Figure 12 corresponds to the inside region of the cell without reversed flow. Red is the high value of $\mathrm{V}_{\theta}$, blue is the is low, respectively.

As a whole, it is observed for all cross sections that the streamline near hub is almost straight from RR1 to RR3. For the cross section A (Figure 12a), the flow turns a little outward at the upper part of the cross section, but the flow pattern is almost regular. For the cross section B (Figure 12b), at the upper part of the flow path, the flow turns entirely outward, so that the structure of a large reversed flow has been formed. And it is found that the color contour shows red near the outer casing on RR1, where the value of $\mathrm{V}_{\theta}$ is high. For the cross section $\mathrm{C}$ (Figure 12c), the flow pattern is similar to that on the cross section A. However, there is a difference in the color contour of $\mathrm{V}_{\theta}$; for the cross section $\mathrm{A}$, the value of $\mathrm{V}_{\theta}$ at the upper part of the flow path becomes small, whereas for the cross section $\mathrm{C}$ the value of $\mathrm{V}_{\theta}$ near the mid-flow path becomes small.

\section{CONCLUSIONS}

The unsteady flow fields downstream of a rotor with a rotating stall cell in a high-specific-speed diagonal-flow fan were clarified experimentally. In order to know the behavior of the stall cell, the measurement with a single-slant hot-wire probe was conducted, and the data were processed by use of the DPLA technique. The main conclusions were as follows:

1. The spanwise size of the cell is larger at the rotor outlet than at the inlet.

2. Strongly reversed flow exists at the blade SS side and far from the outer casing.

3. Circumferential velocity becomes the highest at the cell's trailing edge.

4. Spanwise velocity is strongly outwards under the rotating stall condition. 
5. The reversed-flow region is rapidly weakened as the distance becomes far from the rotor.

6. Under rotating stall conditions, the flow out of the cell is relatively regular. Even if inside the cell, there is a cross section that has a flow pattern similar to that out of the cell.

\section{NOMENCLATURE}

DP Design point of test fan

LPF Low-pass filtered

LE Leading edge of rotor blade

$\mathrm{P}_{\mathrm{d}} \quad$ Dynamic pressure based on $\mathrm{U}_{\mathrm{t}},\left(=\rho \mathrm{U}_{\mathrm{t}}^{2} / 2\right)$

$\mathrm{RS}_{\text {ref }}$ Rotating stall reference point

SP Stall point of test fan

TC Tip clearance

TE Trailing edge of rotor blade

TP Trigger point

$\mathrm{U}_{\mathrm{t}} \quad$ Blade tip speed

$\mathrm{V}_{\mathrm{m}} \quad$ Meridional velocity component

$\mathrm{V}_{\theta} \quad$ Circumferential velocity component

$\mathrm{V}_{\mathrm{n}} \quad$ Spanwise velocity component

\section{Greek}

\section{$\phi$}

Flow-rate coefficient (the mean axial velocity divided by $U_{t}$ )

$\eta \quad$ Efficiency

$\theta \quad$ Circumferential direction

$\rho \quad$ Density of air

$\tau \quad$ Torque coefficient

$\psi \quad$ Total pressure coefficient (the total pressure rise devided by $\mathrm{P}_{\mathrm{d}}$ )

\section{REFERENCES}

Inoue, M., Kuroumaru, M., Tanino, T., and Furukawa, M. 2000. Propagation of multiple short-length-scale stall cells in an axial compressor rotor. ASME Journal of Turbomachinery 122:45.

Kaneko, K., Setoguchi, T., and Muraoka, A. 1993. Internal flow of high specific-speed diagonal flow fan in low flow range. Proceedings of the 4th Asian International Conference on Fluid Machinery, 83. Suzho, China.

Kaneko, K., Muraoka, A., Shiraishi, K., and Setoguchi, T. 1995. Unsteady flow in diagonal flow fan in low flow range. Proceedings of the 6th Asian Congress of Fluid Mechanics, Vol. 2, 1488. Singapore.

Kaneko, K., Shiomi, N., Muraoka, A., and Setoguchi, T. 1997. Internal flow of high specific speed diagonal flow fan with rotating stall. Proceedings of the 5th Asian International Conference on Fluid Machinery, 795. Seoul, Korea.

Kaneko, K., Cai, W.-X., Shiomi, N., Zhang, D.-L., and Setoguchi, T. 2000. Behavior of tip clearance flow in high specific-speed diagonal flow fan. Proceedings of the 6th Asian International Conference on Fluid Machinery, 31. Johor-Bahru, Malaysia.

Kuroumaru, M., Inoue, M., Furukawa, M., Tanino, T., and Maeda, S. 1999. Making of stall cell animation by double-phase-locked averaging method. Turbomachinery 27:502. [In Japanese.]

Moore, F. K., and Greitzer, E. M. 1986. A theory of post-stall transients in axial compressor systems: I, II. ASME Journal of Engineering for Gas Turbine and Power 108:68.

Poensgen, C. A., and Gallus, H. E. 1996. Rotating stall in a single-stage axial flow compressor. ASME Journal of Turbomachinery 118:189.

Saxer-Felice, H. M., Saxer, A., Inderbitzin, A., and Gyarmathy, G. 1998. Prediction and measurement of rotating stall cells in an axial compressor. ASME Paper, 98-GT-227. Stockholm, Sweden.

Shiomi, N., Cai, W. X., Muraoka, A., Kaneko, K., and Setoguchi, T. 2000. Behavior of rotating stall cell in a high specific-speed diagonal flow fan. Proceedings of the 6th Asian Symposium on Visualization (CD-ROM Procs.), Paper no. 183. Pusan, Korea. 

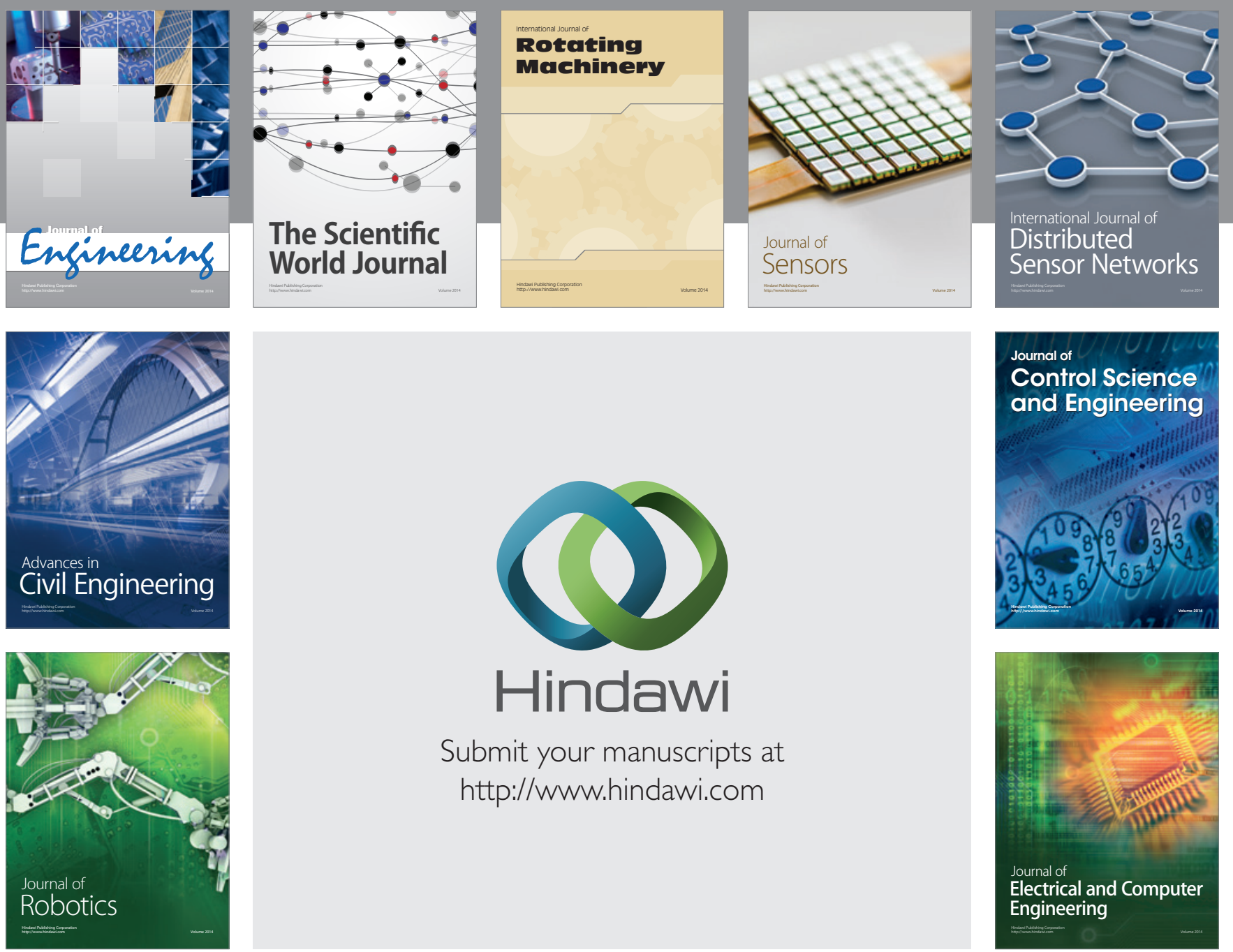

Submit your manuscripts at

http://www.hindawi.com
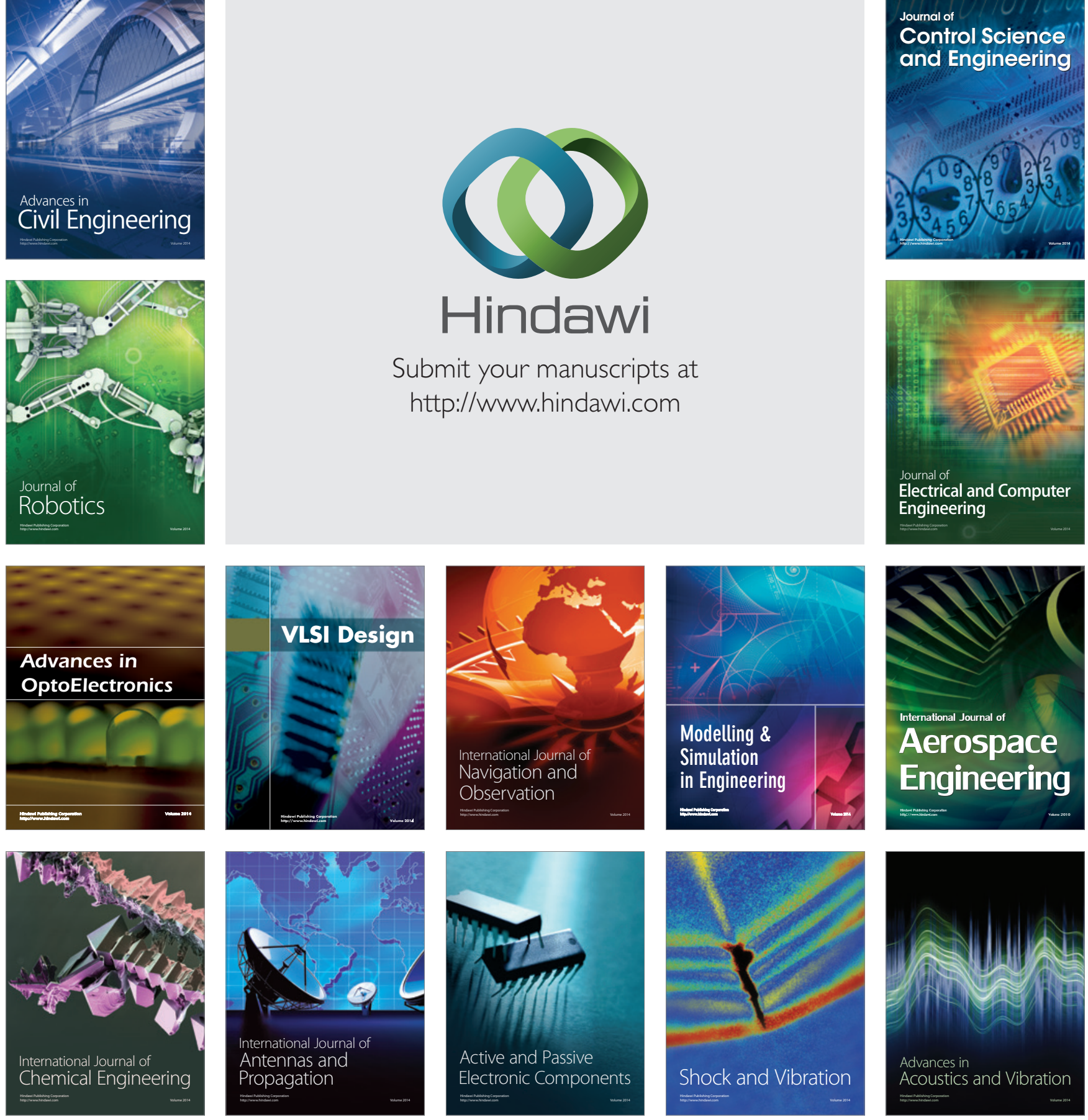